Proc $2^{\text {nd }}$ APCRS

\title{
Coral Reef Restoration Plan of Thailand
}

\author{
Pinsak SURASWADI ${ }^{1, *}$ and Thamasak YEEMIN ${ }^{2}$
}

${ }^{1}$ Department of Marine and Coastal Resources, 120 Moo 3 Cheangwattana 7 Rd, Laksi, Bangkok 10210 Thailand

${ }^{2}$ Marine Biodiversity Research Group, Department of Biology, Faculty of Science, Ramkhamhaeng University, Huamark, Bangkok 10240 Thailand

* Corresponding author: Pinsak SURASWADI

E-mail: pinsak@hotmail.com

\begin{abstract}
The Department of Marine and Coastal Resources (DMCR) together with the Marine Biodiversity Research Group of Ramkhamhaeng University have drafted a Thailand coral reef action plan. Secondary data on the status of coral reef, threats and types of use were collected. Various concepts of reef restoration and techniques were discussed in an expert meeting group to formulate a concept of reef restoration for Thailand. The concept and data were then verified and consulted with scientists and stakeholders in 4 coral reef vicinity areas. Following this, the coral reef restoration action plan was drafted and priority areas were identified and then approved by the DMCR coral reef committee. The plan was approved in a final meeting with various stakeholders and government organizations. 96,000 rai (153 sq.km) of Thailand's coral reef are categorized into 4 different stages depending on their status threats and type of use. Category 1 , in which coral reef is in a degraded status and is used for tourism, was the priority area for restoration. This area includes 24 coral reef sites covering 7,843 rai (12.5 sq. $\mathrm{km})$. The coral reef restoration plan starts using passive restoration by reducing threats, including tourism, water pollution, sedimentation and fishery, by 4 strategies and 15 measures. Then active restoration by a suitable coral reef propagation technique will be applied.
\end{abstract}

Keywords Coral, restoration, action plan, management, Thailand

\section{Introduction}

The coral reef in Thailand covers an area of 96,000 rai (153 ha); 47,000 rai in the Gulf of Thailand and 49,000 rai in the Andaman Coast. Recent data shows that almost $37 \%$ of coral reef is degraded, of which $24 \%$ in the Gulf of Thailand and 50\% in the Andaman Coast. The causes of degradation are due to both natural and human causes, however unsustainable uses by human activities related to fishery and tourism seem to be the most obvious one. Tourism with its various development stages are the most severe cause especially during the construction stage when inappropriate sediment control measures are used and regulated. The consequences of coral reef degradation include reduced productiveness of Thai sea and an increase in conflicts between different sectors that use the sea resources (Yeemin et al. 2006).

Nowadays, many studies have been performed to restore the coral reef, and the results of them have developed into a concept of coral reef restoration. Proper guidelines, measures and regulations have been made to reduce the impact from various threats. Different active restoration measures such as coral propagation and coral transplants have been studied (Heeger and Soto 2000; Job et al. 2003; Rinkevich 2005; Yeemin et al. 2006; Edwards and Gomez, 2007; Rinkevich 2008; Edwards 2010).

In order to achieve successful coral reef restoration in 
Thailand, a coral reef restoration plan should be made. Thus, the Department of Marine and Coastal Resources as a responsible government agency and the Marine Biodiversity Research Group at Ramkhamhaeng University drafted a plan together with coral reef scientists, related government agencies and different stakeholders.

\section{Material and methods}

\section{Data collection}

Secondary data of coral reef status and threats in Thailand were collected from different government agencies and university laboratories. Studies on coral reef restoration both in Thailand and elsewhere were gathered relating to different issues including ecology, economic, social, law and regulation, and management. The data were then analyzed and synthesized into a meeting paper including data on (1) status and trend of coral reef (2) threats to coral reef (3) concept and guideline of reef restoration (4) measures and regulations to reduce threats (5) priority reef restoration areas.

\section{Expert meeting}

An expert meeting was held in Bangkok, between 30 coral reef experts from government agencies, universities and private sectors, in order to discuss and comment on the draft meeting paper. Concept and flowchart of reef restoration was re-examined and adjusted.

\section{Stakeholders meeting}

Four stakeholder meetings were held in coral reef vicinity areas around Thailand, two in the Gulf of Thailand and two in the Andaman Coast, including Bangkok, Trat, Surat Thani and Phuket. The meetings consisted of 20 participants from the tourism sector, fisherman, NGOs, and government agencies in order to discuss and give comment to the draft meeting paper, restoration concept and diagram.

\section{DMCR coral reef committee's meeting}

The coral reef restoration plan was then drafted from the past meetings and submitted to the DMCR coral reef committee which consisted of high level DMCR staff and reef managers in order to get additional suggestions and comments.

\section{Public consultation meeting}

A public consultation meeting was held in Bangkok with 80 participants from various sectors such as regulated agencies, related national management committees and the private sector in order to finalize the draft coral reef restoration plan.

\section{Results}

\section{Concept of coral reef restoration}

Due to a rapid growth in population and rapid development in coastal areas, coral reef is in a degraded status. Thus reef restoration should be planned and acted following the 5 procedures below:

\section{1) Restoration site selection}

Coral reef should be prioritized for restoration by their status, level of threat and type of use. Coral reefs in Thailand are categorized into 4 stages:

Stage 1: coral reef is in poor to very poor condition, and is threatened by tourism activity.

Stage 2: coral reef is in moderate, good and very good condition, and is threatened by tourism activity.

Stage 3: coral reef is in poor to very poor condition, and has no tourism activity.

Stage 4: coral reef is in moderate, good and very good condition, and has no tourism activity.

Coral reef site that should be first prioritized for restoration are those in stage 1 due to its high influence from human threats, high trend to be more degraded and high influence on the country's economy.

Coral reef sites that should be second prioritized for restoration are those in stage 2 due to its high influence from human activities, high trends to be more degraded and high influence on the country's economy.

\section{2) Evaluate reef restoration potential}

Coral reef restoration potential in the target area has to be evaluated by considering environmental conditions and whether they are suitable for coral growth or not, if not suitable measures and regulations for improving environmental conditions have to be applied. If conditions 
are suitable for coral growth, the hard substrate has to be evaluated for coral growth, if not suitable measures for improving the hard substrate have to be applied. If substrate is suitable, then the rate of natural coral recruitment has to be evaluated, if suitable reef restoration should be allowed to proceed naturally. If rate of natural recruitment is not enough, proper active restoration such as coral propagation should be applied (Figure 1).

\section{3) Identify proper active restore}

In case of inadequate natural coral recruitment, a proper active restoration method should be applied such as

- Coral propagation from fragment in the same area

- Coral propagation from fragment in vicinity area

- Coral propagation from sexual reproduction

Different coral restoration methods can be applied together depending on the condition in order to increase the effectiveness of the project.

\section{4) Evaluate the project feasibility}

Evaluate feasibility of the project in the area to see whether it is capable or not by public participation with stakeholder. If it is not technically viable, identify the research needed.

\section{5) Restoration and evaluation}

Apply proper restoration techniques and evaluate the project in short term and long term.

Strategy for improving environment conditions

In the area where environmental conditions are not suitable for coral growth, restoration has to start from improving environmental conditions by reducing the threats as follows:

\section{Priority area for coral restoration}

The first priority areas for coral restoration in Thailand includes Koh Tao, Koh Phangan, Koh Samui Suratthani Province; Koh Chang Trat Province; Koh Samed Rayong Province; Koh Laan, Koh Phai Chonburi province; Koh Racha Phuket Province; Koh Yao Moi, Koh Yao Yai Phang-Nga Province; and Koh PhiPhi Krabi Province, which includes 24 coral reef sites covering 7,843 rai (12.5 sq.km).

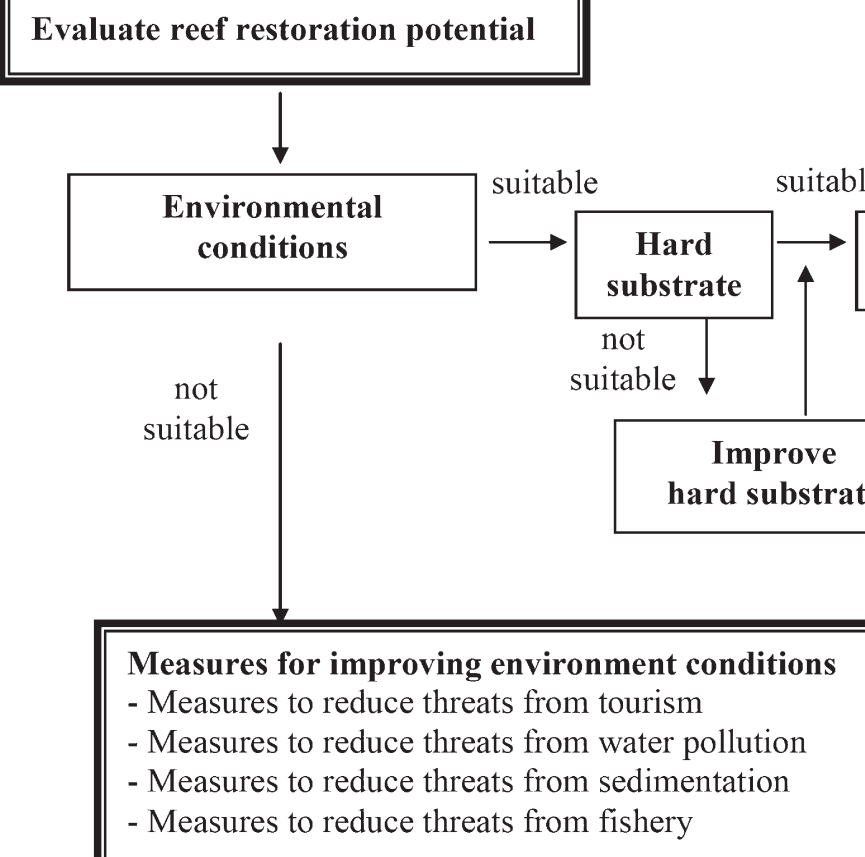

Fig. 1 Reef restoration potential evaluation diagram 
Strategy $1:$ Reduce threats from tourism

Measure $1:$ Reduce threats from diving activities to coral reef

Measure 2 : Build awareness, increase local knowledge and capacity management

Measure 4 : Build up monitoring plan for tourism activity
1) Control and monitor divers to avoid contact and damage to coral reef

2) Avoid bringing divers to risky and fragile reef area

3) Zoning reef area

4) Encourage tourist boats to have proper waste and garbage management

5) Apply mooring buoy in all diving areas

6) Encourage to use snorkeling trails

1) Build up tourist center

2) Train divers before going into water

3) Train guides and staff for coral reef conservation

4) Train local people in tourist area for coral conservation

5) Train boat staff for using mooring buoy

6) Produce coral reef conservation media such as posters, videos

7) Promote coral conservation through local media

1) Apply carrying capacity in tourism site

2) Encourage to use tourist center

3) Apply code of practice to reduce impact from tourism activity

4) Create networking between stakeholders for co-management

5) Set up a committee responsible for mooring buoy management

6) Create regulations for tourist operators to use mooring buoy and to have proper waste management

1) Monitor impact from tourism activity to coral reef

2) Monitor coral reef status in tourism site

3) Encourage local participation in monitoring plan

4) Study on improving monitoring techniques related to tourism activity

\section{Strategy 2 : Reduce threats from water pollution}

Measure 1 : Evaluate water quality in coral 1 1) Evaluate water quality in coral reef area

reef area

Measure 2 : Control water quality within suitable conditions

1) Support proper waste water treatment system for households around coral reef area

2) Support wetland conservation around coral reef area

3) Support commercial fishing boats and tourist boats to have a waste water holding tank

4) Encourage fish piers to have proper waste water treatment

5) Prevent draining of ballast water near coral reef area

6) Support using eco-friendly sun protection lotion

7) Promote closed aquaculture system

Measure 3 : Build awareness, increase

1) Promote knowledge about impact from water pollution to coral reef

local knowledge and capacity

2) Campaign and promote water saving through local media

3) Set up youth water conservation group

4) Display water quality data in the tourism site

Measure 4 : Encourage integrated and comanagement

1) Practice on mitigation of water pollution incidents between responsible agencies and stakeholder

2) Publish guideline about mitigation of water pollution incidents

Measure $5:$ Build up monitoring plan for water quality around coral reef area

1) Monitor water quality in coral reef area

2) Install online water quality measurement instrument in coral reef site 3) Monitor and evaluate water discharge from local community

\section{Strategy 3 : Reduce threats from sedimentation}

Measure $1:$ Encourage proper integrated coastal zone management

1) Reduce deforestation and promote reforestation in coastal areas

2) Promote proper crop management to reduce soil erosion

3) Campaign and promote integrated zone management

4) Set up local task force to access ecological mitigation plan in EIA, to be done by contractor

5) Legislate local regulation for development and construction

6) Train local staff and stakeholders on coastal zone management

Measure 2 : Reduce threats from coastal

1) Use vetiver glass to prevent soil erosion

development

2) Legislate regulation to prevent soil erosion and control building during rainy season

3) Control underwater mining to reduce sediment disturbance

4) Monitoring suspended solid and sedimentation in coral reef area 


\begin{tabular}{|c|c|}
\hline Strategy 4 : Reduce threats from fishery & \\
\hline \multirow{6}{*}{$\begin{array}{l}\text { Measure } 1: \text { Reduce threats from fishery to } \\
\text { coral reef }\end{array}$} & 1) Inhibit using destructive fishing in coral reef area \\
\hline & 2) Training illegal fisherman to use appropriate fishing gear \\
\hline & 3) Prevent trash being discarded from fishing boats \\
\hline & $\begin{array}{l}\text { 4) Use artificial reef to prevent coral destruction by illegal trawler and push } \\
\text { nets }\end{array}$ \\
\hline & 5) Promote aquaculture of ornamental fish \\
\hline & 6) Promote cleanup campaign in coral reef area \\
\hline \multirow{3}{*}{$\begin{array}{l}\text { Measure } 2: \text { Build awareness, increase } \\
\text { local knowledge and capacity }\end{array}$} & 1) Training fishery staff on coral conservation \\
\hline & 2) Training fisherman on coral conservation \\
\hline & 3) Promote coral conservation through local media \\
\hline \multirow{3}{*}{$\begin{array}{l}\text { Measure } 3 \text { : Encourage integrated fishery } \\
\text { management }\end{array}$} & 1) Set up local network for integrated fishery management \\
\hline & $\begin{array}{l}\text { 2) Set up fishery coordination center as information center, receive complaints } \\
\text { and suggestions }\end{array}$ \\
\hline & 3) Zoning fishery area \\
\hline \multirow{3}{*}{$\begin{array}{l}\text { Measure } 4 \text { : Build up monitoring plan for } \\
\text { fishery around coral reef area }\end{array}$} & 1) Monitor fishery around coral reef area \\
\hline & 2) Set up local fishery patrol network \\
\hline & $\begin{array}{l}\text { 3) Study on improving monitoring techniques related to fishing around coral } \\
\text { reef area }\end{array}$ \\
\hline
\end{tabular}

\section{Discussion}

During the last two decades, central agencies, provincial governments, local district administration authorities and the private sector have recognized the importance of coral reef management and coral restoration. Several coral reef restoration projects have shown the improvement of coral reef conditions through preventive measures, raising public awareness at all education levels and active coral reef restoration (Yeemin et al. 2006).

It is suggested that prevention measures and the mitigation of coral reef damage, through coral reef zoning and temporary closure of degraded coral reefs, are important interventions under the integrated coastal zone management approach (Wooldridge 2009; Melbourne-Thomas et al. 2011). Coral reef restoration projects are remarkably important activities which support the adequate protection of important reef sites for spawning and nursery areas of marine organisms (Mapstone et al. 2008). Moreover there has been a trend toward adaptive management of marine protected areas and the concepts of adaptive planning which provide opportunities for effective management of coral reefs in Thailand and other countries (Ban et al. 2011).

\section{References}

Ban NC, Adams VM, Almany GR, Ban S, Cinner JE, McCook LJ, Mills M, Pressey RL, White A (2011) Designing, implementing and managing marine protected areas: Emerging trends and opportunities for coral reef nations. J Exp Mar Biol Ecol 408: 21-31

Edwards, A. J. 2010. Reef Rehabilitation Manual. Coral Reef Targeted Research \& Capacity Building for Management Program: St Lucia, Australia. ii + 166 pp

Edwards AJ, Gomez Ed (2007) Reef Restoration Concepts and Guidelines: making sensible management choices in the face of uncertainty. Coral Reef Targeted Research \& Capacity Building for Management Programme: St Lucia, Australia. iv $+38 \mathrm{pp}$

Heeger T, Sotto, F (eds) (2000) Coral Farming: A Tool for Reef Rehabilitation and Community Ecotourism. German Ministry of Environment (BMU), German Technical Cooperation and Tropical Ecology program (GTZ-TÖB), Philippines. $94 \mathrm{pp}$

Job S, Schrimm M, Morancy R (2003) Reef Restoration: Practical guide for management and decision-making. Carex Environnement, Ministère de l'Écologie et du Développement Durable, IFRECOR. $32 \mathrm{pp}$

Mapstone BD, Little LR, Punt AE, Davies CR, Smith ADM, Pantus F, McDonald AD, Williams AJ, Jonesh A (2008) Management strategy evaluation for line fishing in the Great Barrier Reef: Balancing conservation and multi- 
sector fishery objectives. Fish Res 94: 315-329.

Melbourne-Thomas J, Johnson CR, Aliño PM, Geronimo RC, Villanoy CL, Gurney GG (2011) A multi-scale biophysical model to inform regional management of coral reefs in the western Philippines and South China Sea. Environ Model Softw 26: 66-82

Rinkevich B (2005) Conservation of coral reefs through active restoration measures: recent approaches and last decade progress. Environ Sci Technol 39 (12), 4333-4342

Rinkevich B (2008) Management of coral reefs: We have gone wrong when neglecting active reef restoration. Mar Poll Bull 56: 1821-1824

Wooldridge SA (2009) Water quality and coral bleaching thresholds: Formalising the linkage for the inshore reefs of the Great Barrier Reef, Australia. Mar Poll Bull 58: 745-751

Yeemin T, Sutthacheep M, Pettongma R (2006) Coral reef restoration projects in Thailand. Ocean Coast Manage 49, $562-575$

(C) Japanese Coral Reef Society 